International Journal of Child, Youth and Family Studies (2016) 7(3/4): 364-380

DOI: http://dx.doi.org/10.18357/ijcyfs73-4201616090

\title{
YOUTH MENTORSHIP AS NEOLIBERAL SUBJECT FORMATION
}

\section{Matty Hillman}

\begin{abstract}
This paper critically analyzes how youth mentorship discourse in North America supports hegemonic and normative values of patriarchy, gender role expectations, and negative youth stereotypes. Utilizing critical discourse analysis, I identify and make explicit the additional agendas present in youth mentorship programs. Through an examination of the language and rhetorical devices used to promote youth mentorship programs, multiple elements of discourse are identified as supporting the inculcation of youth with neoliberal values such as competition, entrepreneurism, and self-regulation. The implications of this analysis suggest the continual and increasing presence of neoliberal and corporate capitalistic values in the once publicly funded welfare state.
\end{abstract}

Keywords: youth mentorship, neoliberalism, critical discourse analysis, child and youth care

Matty Hillman is an MA student in the School of Child and Youth Care at the University of Victoria, 3800 Finnerty Road, Victoria, BC V8W 2Y2. Email: mattyhillman@gmail.com 
This paper critically examines both the implicit and explicit discourses found in wellknown youth mentorship programs firmly established in North America. Utilizing a critical governmentality lens and borrowing from critical discourse analysis (CDA; Fairclough, 1992), I examine text material that promotes youth mentorship programming. I demonstrate that, wellintentioned as these programs may be, in actuality they support oppressive discourses such as patriarchy and gender role expectations. Furthermore, due to the recent increasing presence of corporate and private interests in the field of positive youth development, I argue that it has become an emergent goal of the mentorship programming movement to promote the values and characteristics of the business-savvy neoliberal citizen.

Considering the dominance of Western developmental psychology discourse in child and youth care literature and practice (Pacini-Ketchabaw, 2011), and the increasing embrace of neoliberal practices in many Western liberal democratic states (Kennelly, 2011), identifying and making explicit the intersection of these two hegemonic elements is important and timely. In critical youth studies it is imperative that we examine the values that are being promoted as necessary for successful youth development, and ask whom those values primarily benefit and what additional agendas are being fulfilled. One of the main goals of this paper is to draw attention to how youth mentorship programs support normative development of the youth they serve in the hope of producing competent, productive, and healthy young people. Through this process, these programs are asked to assist with the creation of ideal neoliberal citizens primed to support the values of a Western-Eurocentric, capitalistic state. This paper aims to highlight the problematic nature of neoliberal influence on youth mentorship programming, and show that it leads to an overemphasis on individualized models of development, and a disregard for the widespread structural inequalities found in North America.

Two widely known and well-recognized organizations, Boys to Men and Big Brothers Big Sisters (BB/BS), and the mentorship models they espouse, are examined in this paper by way of text-based discourse retrieved from their promotional materials and websites. Offering both community and school-based mentorship programs, these organizations claim to match thousands of youth with adult mentors yearly in countries across the globe. The strong North American presence and growing international reach of these programs makes them both relevant and appropriate for critical examination.

A critical analysis that seeks to problematize, probe, and critique societal assumptions does so in the spirit of emancipation from the predetermined outcomes for youth development that are desired by those in authority. As will be shown in this paper, many of these desired youth outcomes support gender and class stratification and have been constructed not by the youth themselves, but by authoritarian institutions with vested interests. Through inquiry and an exploration of implications, a more socially just and reflexive practice of helping others can be achieved. 
International Journal of Child, Youth and Family Studies (2016) 7(3/4): 364-380

Finally, it is worth noting that this paper provides only a partial perspective on youth mentorship programming, charting the desired outcomes for youth as based on two programs' promotional literature. This is not to dismiss the possibility that youth and youth mentors, through their shared values and emerging relationships, may have the opportunity to resist the neoliberal values promoted by these programs.

\section{The Neoliberal Context}

Neoliberalism comprises a set of economic theories, policies, and political practices that seek to liberalize free markets through economic deregulation, elimination of tariffs, and cuts to social and health services (Kennelly, 2011). With regard to its effects on the self, neoliberalism promotes an environment that values individualism, self-responsibility, and freedom of choice in employment and identity formation, as well as traits of self-monitoring and self-surveillance (Phoenix, 2003). However, these apparent freedoms and traits come at a cost. The core neoliberal value of competition has been widely critiqued as normalizing oppression, creating individualistic and victim-blaming practices that promote the view that what happens to one is the product of individual choices autonomously made (Phoenix, 2003); the presence and effects of structural inequalities in the life trajectories of individuals are minimized or ignored. Furthermore, due to its widespread acceptance as a philosophy of our time, neoliberalism often acts as an insidious form of social control, effectively regulating individual citizens by subtle persuasion rather than direct threat (Rose, 1999).

Neoliberal policies and ideologies have been described as a form of governmentality with pervasive influence, and a range that "reaches from the soul of the citizen-subject to education policy to practices of the empire” (Brown, 2005, p. 38). Under neoliberal influence, education policy is designed to produce citizens ready to seek individual success in the modern global economy; and it aims to give students a complex set of skills imbued with the tenets of autonomy, choice, and competition (Mitchell, 2003). When such educational policy is coupled with the Western construction of young people (ages 13-21) as dependent, irrational, and in need of guidance (Skott-Myhre, 2008), educational programs infused with neoliberal values proliferate. These programs are formulated with the intention of influencing these citizens-in-themaking with the "specific qualities and characteristics that are desirable to the nation-state" (Kennelly, 2011, p.4). Given the pervasive nature of neoliberal governmentality in multiple aspects of a young person's life, youth mentorship programs can be viewed as a form of developmentally based curriculum designed not only to engage young people with role models who will guide, teach, and inspire, but also to enclose young people in a normative framework infused with state-supported ideals.

\section{Theoretical Orientation}

In the work of Foucault (1972), discourse is considered to be a sequence of signs that assign meaning to and among objects, subjects, and statements. Elements of discourse may take 
the form of ideas, attitudes, beliefs, and practices that are grouped together as they share a similar force or act together in a similar way. Discourses can be related to power through rules of inclusion and exclusion - they construct not only the understood truths of our times but also how, where, and who is privileged to speak to them. Discourses shape society and at the same time are shaped by it; economic, social, and cultural ideologies and policy are moulded by these discourses.

Pioneered by Norman Fairclough, Ruth Wodak, Teun van Dijk, and others, critical discourse analysis (CDA) emerged in the late 1970s from the University of East Anglia and has since become one of the most well-known and influential branches of discourse analysis (Blommaert \& Bulcaen, 2000). In CDA, institutional, political, gender, and media discourses as related to struggle and conflict are analyzed, with specific emphasis on the relationship between language and power (Wodak \& Meyer, 2001). Because these structural relationships of dominance, discrimination, control, and power as manifested in language can be opaque (Wodak, 2011), CDA systematically analyzes discourse to identify and make transparent various processes that can be viewed as hegemonic and oppressive, such as democratization, commodification, and technologization (Fairclough, 1992).

Because CDA seeks to identify and make explicit the often hidden discourses and hegemonic power structures in society, it is a strong theoretical framework for unpacking the implicit normative discourses found in youth development programming. Often, in modern society, the opaque agendas and discrete forms of regulation that governments and others in positions of power use to keep the status quo are not fully evident or knowable: in the Foucauldian understanding of the state, individual subject discipline and societal control often occur through covert means (Kennelly, 2011). Thus, governmentality moves beyond directly observable policies and legal decisions to include a variety of authorities over subjects of the state, including self-discipline. In other words, the options that evolve to be considered thinkable for specific subjects also ensure the legitimacy and ongoing survival of the state, in its current conceptualization (Kennelly, 2011).

Rose (1993) has further expanded on this concept of governmentality by identifying the insidious nature of many of the disciplinary apparatuses of the modern nation-state. Rather than applying overt forms of domination, current neoliberal governance seeks to regulate the choices that citizen-subjects view as available to themselves. No longer governed by authoritarian political rule, the subject is expected to become self-governing by internalizing the primary tenets of neoliberalism such as competition and self-responsibility. The neoliberal state enlists institutions such as schools, families, and youth mentorship programs to instill these tenets and assist in the creation of the self-governing subject, who in turn is expected to uphold and legitimize the actions and values of the nation-state. 
International Journal of Child, Youth and Family Studies (2016) 7(3/4): 364-380

\section{Developmental Youth Programming in a Neoliberal World}

In order to foreground the prescriptive nature of youth mentorship programs, it is necessary to review the rise of the developmental psychology model in child and youth care discourse, and its intersection with the individualistic values of the neoliberal state. Skott-Myhre (2008) reminds us that "young people in Western societies are defined by developmental psychology as incapable of fully producing a core self capable of full rationality, and as a result, lack the maturity necessary to make reasonable decisions about their lives” (p. 13). Valuing objective observation and measurement of chronological human development, developmental psychology applies a linear and sequential process to the lifespan. This contributes to a discourse that conceives of young people as proto-adults, requiring guidance and support to successfully navigate the development process. This idea of progression in competence and maturity as one ages has been associated with a discourse that models ideal-typical citizen-subjects as those who are knowable, known, docile, and productive (Burman, 2008). Throughout the process of moulding the citizen-subject into someone who can navigate the current challenges of global capitalism, the developmental psychology model of normative human development is constantly influencing and being influenced by social, political, and cultural institutions (Pacini-Ketchabaw, 2011). Elements such as individualism, esteem, purpose, boundary, and assertion are present in the prevailing discourse as desirable and even required elements of healthy youth development in an increasingly individualistic and competitive world (Skott-Myhre, 2008).

When dominant notions of normative development view young people as still developing into fully functioning, productive, and responsible adults, a perceived need is created for adultdriven interventions. Youth programs grounded in these developmental theories interact with prevailing social, cultural, and political norms to provide guidelines for the creation of productive and healthy adults. In Youth Rising? The Politics of Youth in the Global Economy, Sukarieh and Tannock (2015) state, “The youth developmental framework is the most important conceptual model for thinking about and working with that ever expanding segment of our population that we have collectively come to define as youth” (p. 19). The authors go on to outline some of the more well-known and widely embraced developmental models of youth programming such as “The Five Cs: competence, character, confidence, connection, and caring” (Lerner, 2004), as well as Benson's (1997) 40 developmental assets that are required for healthy youth development. The specific competencies, assets, or other standardized forms of evaluation or support offered by these and other development frameworks are secondary components to the more pervasive notion of the "successful" adult individual the programs strive to create - a resourceful and resilient young person, equipped with the skills and knowledge necessary to prosper and flourish in our complex and globalized world. Specifically, positive youth developmental discourse aims to promote neoliberal ideals, particularly those pertaining to personal qualities of young citizens, such as personal responsibility, self-sufficiency, and entrepreneurialism (Sukarieh \&Tannock, 2015). 
International Journal of Child, Youth and Family Studies (2016) 7(3/4): 364-380

\section{Critical Discourse Analysis of Current Trends in Youth Mentorship}

The following sections of this paper will review the aforementioned youth mentorship programs, Boys to Men and BB/BS. Following a brief examination of youth mentorship statistics and the various forms that programs can take, I will investigate, through a CDA lens, several areas of youth mentorship discourse, including the use of specific language and rhetorical devices such as risk management and critical window, and the intersection of youth mentorship and corporate capitalistic interests. Through deeper analysis it becomes clear that additional agendas, such as the production of a narrowly defined ideal citizen-subject, and the persistent support of problematic youth stereotypes, are embedded within these programs' desired outcomes.

Youth mentorship programs have seen an increase in popularity and prominence in the last decade (DuBois, Portillo, Rhodes, Silverthorn, \& Valentine, 2011). In the United States, the National Mentoring Partnership (MENTOR) currently posts research data claiming that over 4.5 million of today's youth will receive some form of structured adult mentorship while growing up (National Mentoring Partnership [MENTOR]: “About MENTOR”, 2016). Mentorship programs take many forms, and embody a large variety of philosophies. Many programs aim solely to support healthy development by providing adult mentoring relationships for youth, while others have more focused goals relating to areas such as education and employment (Saito \& Blyth, 1992). Whatever models are applied in the hundreds of mentorship programs currently running in North America, their resource and promotional materials will unsurprisingly promote the positive impact the presence of an mentor may have on the development of a young person, as exemplified by passages like this one from MENTOR's website:

Research confirms that quality mentoring relationships have powerful positive effects on young people in a variety of personal, academic, and professional situations. Ultimately, mentoring connects a young person to personal growth and development, and social and economic opportunity. Yet one in three young people will grow up without this critical asset. (MENTOR: “Mentoring Impact”, 2016)

Furthermore, normative youth development is frequently contrasted with a narrative of troubled, delinquent, and criminalized youth as a phenomenon stemming from the absence of caring and responsible role models. This binary of possible outcomes is strengthened because youth can be identified as becoming, or proto-, citizens. They are "potentially normative and potentially pathological, unfinished products whose indeterminacy provokes the anxiety inherent in this chrono-social category of adolescence” (Elman, 2014, p. 2). Of course this understanding of young people supports positive youth developmental programming, and youth mentorship especially. The resulting message becomes: Youth fortunate enough to find themselves in the presence of a caring, successful, and supportive adult are more likely to become one themselves, while young people left to their own devices constitute a threat to the social order of the nation. 
International Journal of Child, Youth and Family Studies (2016) 7(3/4): 364-380

With centres in North America, Europe, and South Africa, Boys to Men offers schooland community-based programs that match fatherless teenage boys with adult men for weekly discussion groups and outdoor adventure programs. Promoting what are seen as traditional American values, Boys to Men shares roots with Boys’ Town, a boys’ orphanage founded by Roman Catholic priest Edward J. Flanagan in 1917. Further to this stance, an article on the Boys to Men website attempts to invoke the moral authority of the President of the United States:

It's organizations like Boys To Men that President Obama wants to focus on in light of the racial police-community turmoil happening in Ferguson, Missouri after the shooting death of teenager Michael Brown - organizations that highlight the importance of guidance and education. (Cusato, 2014)

The Big Brother Big Sister model (BB/BS), which is focused solely on providing adultyouth mentoring relationships, is perhaps the most well-known program design and has been referred to as a model of "best practice” in youth mentoring (Tierney, Grossman, \& Resch, 1995). The Canadian chapter of this organization is widespread, with locations in every province as well as the Yukon territory, and with over 188 local agencies operating in over 1,000 communities (BB/BS Canada, “Corporate sponsorships”, n.d.).

\section{Risk Language}

The concept of risk has been described as ubiquitous within human service discourse of late modernity (Spence \& Turnbull, 2011). Risk-based language is especially prevalent in youth programming, where it is primarily used to describe the target service-user. This is certainly the case with youth mentorship programs. Recruitment materials often proclaim the opportunity that mentors have to "make a difference" for "troubled" or "at risk" youth in their community. This saviour-themed promotion can be found juxtaposed with fear- and problem-based language that highlights the perceived consequences not only for youth who do not receive structured guidance through a mentor relationship, but for society as a whole.

This attitude of multiple constructs of risk applied to developing youth is not surprising. Young people are seen as concurrently filling the roles of victim and of perpetrator, on the one hand vulnerable to their own choices and biological development, and on the other pathologized as a primary source of current and future social problems (Spence \& Turnbull, 2011). Discourses that depict adolescence as a time of universal psychological and biological crisis regard adolescent bodies as perennially unstable and a problem to be managed, while avoiding the classification of youth as an identity category, akin to and affected by identity categories of race, class, gender, sexuality, and ability, and also affected by cultural and political agendas (Elman, 2014).

Young males above all are seen as exemplifying the trope of the unsupervised youth as a social risk. When this discourse is coupled with either anecdotal or statistical information regarding the proliferation of fatherless boys or out-of-wedlock births, an environment primed 
for mentorship intervention is created. The Boys to Men mentorship program is perhaps the definitive example of youth mentorship programming applying a fear-based and problemsaturated discourse through promotional material, with over-generalized statements such as: "The number of boys growing up without fathers in their lives has reached epidemic proportions", and "High rates of divorce and out-of-wedlock births have created a generation of fatherless boys" (Boys to Men: “The problem”, n.d.). This exhibition of the increased rates of fatherless boys, when connected to the website's plethora of statistics linked to social issues such as " $90 \%$ of homeless children are from fatherless homes", and " $85 \%$ of children with behavioural disorders come from fatherless homes” (Boys to Men: “The problem”, n.d.), contributes to Western discourse regarding the preferred structure of families and communities in multiple ways. First, linking crime, incarceration, and homelessness with fatherless young men suggests mutually exclusive possible social outcomes for male youth, with the desired outcome being almost exclusively dependent on the existence of a positive fatherly role model in a boy's life. The message emerges that boys lucky enough to find themselves growing up in the idealized setting of a Western family, including the presence of both a mother and a father, are much less likely to face these future struggles. Such messages construct a family model comprising a narrow view of normative family values and structure, effectively pathologizing, or even connecting criminality to, any family dynamic that falls outside of this hegemonic discourse (e.g., single-parent families and non-heteronomative parental dynamics). Furthermore, framing successful male development as a task for a capable father or male mentor implies that adults of other genders may not be suitable for this task.

Although a comprehensive account is beyond the scope of this paper, it is important to acknowledge that men, as fathers, have often been utilized as an apparatus of a system of state control based in traditional moral values. Miller (2006) draws attention to a myriad of U.S. federal programs and reforms aimed at combating fatherlessness, including the Responsible Fatherhood Act of 2001. This act provided funds for individual states to create media campaigns in support of two-parent families and responsible parent education.

In addition to considering fathers an integral part of the idealized North American family unit, the state actively supports traditional gender roles through a welfare provision system that focuses on a "father as provider" archetype. Even the United States, a nation known for providing substantially less state support to families than do other advanced capitalistic countries, has been identified as having a two-tiered, gendered, welfare state:

One tier, "welfare", is targeted on the problems of families, serves mainly women and is stingy and intrusive, and another, "social security," is targeted on the problems resulting from labor markets (e.g., retirement), serves (retired) wage-earning men, and offers more generous benefits and honorable treatment. (Orloff \& Monson, 2002, p. 64)

Additionally, Western neoliberal values of responsibility and individuality are baldly expressed on the Boys to Men website. Unsupported, speculative, and hyperbole-laden claims 
such as "The most important factor of whether a boy will thrive or struggle during his teenage years is determined by the quality of the male role models in his life", and "The most at-risk boys have the most dysfunctional male role models” (Boys to Men: What we have learned, n.d.), overstate the importance of a male presence in overall childhood development and life success. Again, the unspoken but underlying message is that many of society's issues (e.g., massive increases in rates of incarceration, and a rise in homelessness and unemployment) stem from the lack of father and son familial relationships. Therefore, the breakdown of the traditional Western family structure is blamed for the declining quality of life for many in North America and simultaneously given responsibility for counteracting that decline. However, such constructed narratives neglect the intersecting structural factors that affect child development including social and class location, income, racism, and educational opportunities and quality.

Furthermore, on the individual level, such narratives encourage mentors and service providers to take pride in engaging in a charitable and philanthropic activity, but do not encourage critical self-reflection about how they may directly or indirectly be supporting oppressive social structures like sexism, racism, classism, and heteronormative expectations. In the narrative found within this mentorship discourse, the emerging issues of our times, "conditions included, but not limited to, increasing economic stratification, impending threats of environmental devastation, mass global migration, and such supranational threats as terrorism” (Kennelly, 2011, p.5), are mostly ignored. Instead, the overarching ideology of mentorship discourse is that individual and familial strength equates to economic and social well-being for both the individual and nationstate. When youth mentors and mentees are inculcated with a belief system that holds the individual and family unit solely accountable for their success or failure, systemic inequalities that affect individual and family outcomes are less likely to be recognized, further entrenching structural oppression.

\section{Critical-Window Language}

The Boys to Men website identifies a "critical window” in middle school (ages 11-13) when intervention in a fatherless boy's life is needed, since "a teenage boy beginning his journey to manhood with no man to guide him will likely lose his way" (Boys to Men: The critical window, n.d.). This section states that a teenage boy without an emotionally available or present father within three years of his $13^{\text {th }}$ birthday is all but guaranteed to succumb to internalized anger from reflections such as, "Why should I care? Nobody else does"; the site continues the tone of unease by stating, "Fatherless boys are far more likely than boys with fathers to drop out of school, abuse drugs or alcohol, go to prison or join a gang” (Boys to Men: The critical window, n.d.).

It is hardly surprising that this youth mentorship program utilizes a "limited window of opportunity” framework, considering the developmentally informed discourse applied by the current positive youth development movement. This discourse is well aligned with neoliberal political and economical ideals since "certain social concepts of developmental time hold considerable political force within ... the arena of political economy” (Skott-Myher, 2008, p. 
45). A progressive stage-based approach to development has been shown to not only support but also mirror the product-oriented values of late capitalism. Wasiak (2011) points out that some of the best-known child development psychologists of the mid-twentieth century, such as Piaget and Erikson, may have gained influence and popularity through society's misinterpretation of their theories as being aligned with the standardized and product-driven industrial environment of the time. In other words, a capitalistic society seeks not only a successful finished product, but an understandable step-by-step method of arriving at one. For example, Erikson's (1950/1993) popular Childhood and Society suggests that successful resolution of each life stage dilemma is required prior to progression to the next stage of development. Wasiak (2011) concludes that the popularity of Erikson's theory is related to its similarities to the large-scale industrial ideology of the time, with an emphasis on linear, stable, and outcome-focused development. Unfortunately, simplifying the ideas of these theorists often overemphasized the importance placed on the finished product over that of the process needed to arrive there. Piaget's theory of cognitive development, which posited an ultimate stage of thinking for a child to obtain, may have been especially vulnerable to appropriation and misunderstanding, considering the political economy and hegemonic subjectivity of the time (Wasiak, 2011).

Reflecting on this understanding of developmental psychology paralleling industrial capitalism, the use of critical-window language in Western mentorship programming becomes more understandable. Relying on research and dominant discourses that identify a sequential process to a young person's development, youth mentorship programs will likely search for a "make-or-break" point beyond which the opportunity to intervene with maximum effectiveness is lost. By using critical-window language to identify a limited opportunity to intervene and successfully redirect a youth's developmental trajectory, a sense of urgency is created. The juxtaposition of this timeline with statistics indicating what can be expected of youth who are not mentored in a timely manner bolsters the alarmist promotional approach employed by this program, and further supports growth in mentorship programming and of the positive youth development movement. With such a large number of young men represented as being in need of mentorship, such a small window of time for reaching them, and such dire possible consequences for failing to do so, the claimed value of the framework is further increased.

The purported critical window for intervention in the youth mentorship model coincides with the youth-subject's imminent entrance into the world of consumerism and employment. Sukarieh and Tannock (2015) remind us that "there has been a long and close relationship between youth and the different stages of capitalism throughout history” (p. 33). Commencing with the first wave of industrialization in the late eighteenth and early nineteenth centuries, the concept of youth was supported through labour recruitment practices adopted by textile factory owners that targeted young, single women. To entice these young women into the gruelling working conditions found in the factories and to reassure their families that they would be safe and provided for, recruiters often framed the experience as similar to family life, offering dormitory-style accommodations and paternalistic supervision. As Dublin (1981) and other 
scholars have pointed out, youth labour recruitment practices and an ethic of corporate paternalism resulted in the creation of normative adolescent labour experiences for young women. This environment of an age- and gender-based community helped facilitate a cultural identity and social relations for young female employees. It also fostered a new-found sense of freedom and independence for some women. Despite long arduous hours and six-day work weeks, "mill girls" were able to engage city life together, frequenting evening concerts, and reading groups, and so on. Furthermore, although wages were meager and the bulk was often sent home to support families, some women found themselves with a small discretionary income. This new-found financial independence from the patriarchal authority of family homes has been identified as the birth of youth-oriented consumer culture (Sukarieh \& Tannock, 2015).

The practice of targeting youth as a distinct population to draw on as a pool of cheap, compliant labour has continued into the modern period. In the capitalist economy, youth function as a "reserve market of labor" (Marx \& Engels, 1848/1998), as evidenced by the rise of lowwage, low-skill service economy positions that began in post-war North America and subsequently spread around the world (Sukarieh \& Tannock, 2015). Advances in technology, suburbanization, the large-scale entry of women into the workforce, and the "baby boom" population growth all contributed to retail and restaurant employers specifically targeting youth as cheap and disposable temporary labour (Sukarieh \& Tannock, 2015).

Concurrent with mid-century youth labour recruitment was the construction of youth as consumers in capitalistic society. Following the end of the Second World War, businesses sought to anticipate, cater to, and shape changes in youth consumer tastes (Sukarieh \& Tannock, 2015). Some scholars have even argued that the concept of "teenager" as we know it today was invented as a demographic category for marketing targeted goods and services (Palladino, 1996). Youth cannot escape the hegemonic discourse of capitalism that pushes individuals to construct their social identities and the meaning of life through the collection and consumption of material goods (Jansiz, 2014).

Considering the key roles youth have played, and continue to play, as employees and consumers in the capitalistic world, the importance of timing in the mentorship program model becomes salient. The critical window falls within the age range when North American youths are approaching the legal age for employment. Therefore, the involvement of adult role models who are viewed as successful participants in the employed world can play a critical role in promoting capitalistic values to the youth they mentor. This is key to the further growth and existence of a capitalistic nation, for under capitalism, the subject must be turned towards the business of money making (Skott-Myher, 2008). Because youth consumerism, like adult consumerism, is closely linked with waged earnings, continued growth requires that the number of employed youth also continues to grow. The disposable income afforded to employed youth is necessary for sustained growth of the youth-oriented consumer culture. By instilling the virtues of the productive neoliberal citizen in youth approaching the age of employment, as well as contrasting this with an alternative narrative of undesirable tropes involving incarcerated and homeless 
youth, a future generation of employed and consuming citizens is generated. The "critical window" is, in reality, not a limited chronological space for addressing what are perceived as inherent vulnerabilities of youth, but a key opportunity to instill the neoliberal values of financial independence and materialism in those on the cusp of becoming employable, consumer citizens.

\section{The Business of Youth Mentoring}

The Boys to Men website makes explicit reference to the importance of capitalistic ideals and fiscal returns vis-à-vis the youth development movement in an area titled "The Financial Cost”. This section presents statistics regarding the yearly cost to taxpayers in the United States for the total number of men incarcerated ( $\$ 75$ billion), and the individual cost (\$1.7-\$2.3 million) of "a boy leaving high school to enter into a life of crime or drug abuse” (Boys to Men: “The problem”, n.d.). Having previously suggested a link between a lack of role models in the lives of young men and increasing incarceration rates, these references to monetary costs aim to evoke additional support for the vital importance mentorship plays in citizen development and social control within the nation-state. The underlying messages presented on this webpage might be paraphrased as follows:

- A breakdown of the traditional North American family dynamic has resulted in an abundance of male youth finding themselves without father figures.

- These directionless men are to be considered solely responsible for the erosion of America's national unity and quality of life through drastic increases in crime, poverty, and homelessness.

- These social ills have created an enormous financial burden to be shouldered by the taxpayer, therefore substantial effort needs to be invested in mentoring young men lest they become liabilities to the nation's economy and social order.

The BB/BS website is equally clear in their position regarding the financial advantages mentored boys can bring to the state. Neoliberal ideals of employment, self-regulation, and independence are presented as predictable outcomes for young people paired with mentors through this program: "What if ... every child in Canada finishes high school, goes to college or university, gets a job and gives back to their community?” and "The program strives to ... encourage leadership and independent thinking” (BB/BS: Big brothers mentoring, n.d.). Additionally, in the mentor recruitment section, the site applies language that commodifies young people as possible assets and resources to the community and nation-state: "Whether it's in the form of time or money there is no more important investment we as individuals can make than in helping our nation's children realize — and share — their full potential” (BB/BS: About us, n.d.).

Statements regarding program outcomes and youth attributes promoted through the BB/BS program such as, "The program strives to ... instill trust and self-confidence in order to make healthy decisions” (BB/BS: Big brothers mentoring, n.d.) can be considered part of the 
resiliency discourse found in positive youth development programming. The concept of resiliency - the characteristics and conditions that enable certain youth to persevere though adverse circumstances - can be adopted for various political agendas and has been identified as well aligned with the neoliberal, individualist framework of social conformity (Canavan, 2008). Because of its focus on individual strength, resilience ideology can be attractive to anyone wishing to shift attention away from structural inequalities and injustices and centre responsibility for youth development on the individual, family, or community (Sukarieh \& Tannock, 2015). Overemphasizing resilience brings the danger of becoming blind to the various forms of structural inequality (socio-economic, gender, ethnicity, disability, and location-based) and their consequences (Canavan, 2008). Furthermore, since welfare-state funding is contingent on the perception of children and youth as vulnerable and in need, resilience arguments can subvert such claims. In sum, resilience discourse emphasizing the strengths, maturity, and confidence of youth is prized by neoliberal society as grounds for pulling young people into the workforce and undermining the traditional entitlements of welfare-state provision (Sukarieh \& Tannock, 2015).

In addition to soliciting donations and volunteers at the individual level through its website, BB/BS solicits partnerships with corporations in Canada. In their "corporate sponsorship" section the organization describes itself as "one of the most well-known and respected brands in the charitable sector" and "an integral part of the Canadian social fabric" (BB/BS: Corporate sponsorships, n.d.). Furthermore, the website promises that, through association with the $\mathrm{BB} / \mathrm{BS}$ brand and by accessing their substantial geographic reach, partnership with the charity will "influence consumer choice and increase sales and profits" (BB/BS: Corporate sponsorships, n.d.). These narratives openly suggest the financial benefits of allying a charitable organization with the profit-driven business sector, exposing an agenda of leveraging consumer sentiment by connecting altruistic qualities with corporate North America.

\section{Conclusion}

In this paper I have demonstrated, through a critical discourse analysis of promotional text materials, that some of the most well-known and respected youth mentorship programs found in North America serve to promote neoliberal values. As part of a positive youth development movement that has emerged in the last twenty years, these programs seek to support the successful development of the young neoliberal citizen-subject. The directive nature of these programs is problematic for several reasons. The programs disproportionately target marginalized populations, and the personal qualities and attributes the programs desire to instill in young people are narrow in scope, and in support of capitalistic corporate agendas.

Additionally, in their unwavering support of individualistic values and self-responsibility, the discourses examined in these programs’ promotional material distracts from or ignores the systemic and structural inequalities found in the lives of young people, disparities that are particularity relevant to the most marginalized and often-targeted youth populations. 
Programs such as BB/BS and Boys to Men utilize a hegemonic discourse that both implicitly and explicitly supports normative subject formation in the interest of maintaining the status quo. Throughout the recruitment material, description of program outcomes, anecdotes, and statistical information found on their websites, these youth mentorship programs actively promote normative youth stereotypes, traditional family structures, consumerism, and a capitalistic work ethic.

I do not wish through this critical analysis to indicate that programs of this nature apply these values in a completely insidious way, nor that the youth they serve do not possess a degree of autonomy in their ultimate development. Instead, it is the very foundation of how North America, and more generally the "Global North", has come to understand human development that has created value in the qualities these programs promote. The prevalent and hegemonic nature of Western developmental psychology permits only a limited degree of deviance in what is conceived as normative youth development. Therefore, the values and ethics promoted in youth mentorship discourse originate from a much deeper setting than the written material found within individual programs. 
International Journal of Child, Youth and Family Studies (2016) 7(3/4): 364-380

\section{References}

Benson, P. (1997). All kids are our kids. San Francisco, CA: Jossey-Bass.

Big Brothers Big Sisters Canada. (2011). Retrieved December 5, 2015 from http://bigbrothersbigsisters.ca

Big Brothers Big Sisters Canada: About us. (n.d.). Retrieved from http://www.bigbrothersbigsisters.ca/en/home/aboutbbbsc/default.aspx

Big Brothers Big Sisters Canada: Big brothers mentoring. (n.d.) Retrieved from http://www.bigbrothersbigsisters.ca/en/home/mentoringprograms/bigbrothers.aspx

Big Brothers Big Sisters Canada: Corporate sponsorships. (n.d.). Retrieved from http://www.bigbrothersbigsisters.ca/en/home/corporatesponsorships/default.aspx

Blommaert, J., \& Bulcaen, C. (2000). Critical discourse analysis. Annual Review of Anthropology, 29, 447-466.

Boys to Men. (2015). Retrieved December 5, 2015 from http://boystomen.org/

Boys to Men: The critical window is middle school. (n.d.) Retrieved from http://boystomen.org/middle-school-the-critical-window/

Boys to Men: The problem. (n.d.). Retrieved from http://boystomen.org/the-epidemic/

Boys to Men: What we have learned about “The Problem”. (n.d.). Retrieved from http://boystomen.org/what-we-have-learned/

Brown, W. (2005). Edgework: Critical essays on knowledge and politics. Princeton, NJ: Princeton University Press.

Burman, E. (2008). Deconstructing developmental psychology (2nd ed.). New York, NY: Routledge.

Canavan, J. (2008). Resilience. Child Care in Practice, 14(1), 1-7.

Chirimbu, S., Vasilescu, R., \& Barbu-Chirimbu, A. (2011). European youth is the Union's most valuable resource [SSRN Electronic Journal]. doi:10.2139/ssrn.1850888

Cusato, K. (2014). Boys to Men: Mentor program for San Diego youth. Retrieved from http://boystomen.org/success-stories/on-tv/

Dublin, T. (1981). Women at work: The transformation of work and community in Lowell, Massachusetts, 1826-1860. New York, NY: Columbia University Press. 
International Journal of Child, Youth and Family Studies (2016) 7(3/4): 364-380

DuBois, D. L., Portillo, N., Rhodes, J. E., Silverthorn, N., \& Valentine, J. C. (2011). How effective are mentoring programs for youth? A systematic assessment of the evidence. Psychological Science in the Public Interest, 12(2), 57-91.

Elman, J. P. (2014). Chronic youth: Disability, sexuality, and U. S. media cultures of rehabilitation. New York, NY: New York University Press.

Erikson, E. H. (1993). Childhood and society. New York, NY: Norton \& Company. (Original work published 1950)

Fairclough, N. (1992). Discourse and social change. Cambridge, UK: Polity.

Foucault, M. (1972). Archaeology of knowledge. New York, NY: Pantheon.

Jansiz, A. (2014). The ideology of consumption: The challenges facing a consumerist society. Journal of Politics and Law, 7(1), 77-84.

Kennelly, J. (2011). Citizen youth: Culture, activism, and agency in a neoliberal era. New York, NY: Palgrave Macmillan.

Lerner, R. (2004). Liberty: Thriving and civic engagement among America's youth. Thousand Oaks, CA: Sage.

Lewis, J. (1992). Gender and the development of welfare regimes. Journal of European Social Policy, 2(3), 159-173.

Marx, K., \& Engels, F. (1998). The communist manifesto. London, UK: Verso. (Originally published in 1848)

Miller, N. (2006). Disciplining fatherhood: An exercise in constructing responsible fathers. Paper presented at the annual meeting of the American Sociological Association, Montreal, QC. Retrieved from http://citation.allacademic.com/meta/p_mla_apa_research_citation/1/0/4/8/8/p104880_index $\underline{. h t m l}$

Mitchell, K. (2003). Educating the national citizen in neoliberal times: From the multicultural self to the strategic cosmopolitan. Transactions of the Institute of British Geographers, 28, 387-403.

Mukwaya, J. (2001). Preface. In The national youth policy: A vision for youth in the $21^{\text {st }}$ century. Kampala, Uganda: Ministry of Gender, Labour and Social Development.

National Mentoring Partnership: About MENTOR. (2016). Retrieved from http://www.mentoring.org/our-work/about-mentor 
International Journal of Child, Youth and Family Studies (2016) 7(3/4): 364-380

National Mentoring Partnership: Mentoring impact. (2016). Retrieved from http://www.mentoring.org/why-mentoring/mentoring-impact/

Orloff, S., \& Monson, R. (2002). Citizens, workers or fathers? Men in the history of US social policy. In B. Hobson (Ed.), Making men into fathers: Men, masculinities and the social politics of fatherhood (pp. 61-91). Cambridge, UK: Cambridge University Press.

Pacini-Ketchabaw, V. (2011). Rethinking developmental theories in child and youth care. In A. Pence \& J. White (Eds.), Child and youth care: Critical perspectives of pedagogy, practice and policy (pp.19-32). Vancouver, BC: UBC Press.

Palladino, G. (1996). Teenagers: An American history. New York, NY: Basic Books.

Rose, N. (1993). Government, authority, and expertise in advanced liberalism. Economy and Society, 22(3), 283-299.

Rose, N. (1999). Governing the soul: The shaping of the private self. London, UK: Free Association Books.

Saito, R. N., \& Blyth, D. A. (1992). Understanding mentoring relationships. Minneapolis, MN: Search Institute.

Skott-Myhre, H. A. (2008). Youth and subculture as a creative force: Creating new spaces for radical youth work. Toronto, ON: University of Toronto Press.

Spence, J., \& Turnbull, G. (2011). What's at risk? The proliferation of risk across child and youth policy in England. Journal of Youth Studies, 14(8), 939-959.

Sukarieh, M., \& Tannock, S. (2015). Youth rising? The politics of youth in the global economy. NewYork, NY: Taylor \& Francis.

Tierney, J. P., Grossman, J. B., \& Resch, N. L. (1995). Making a difference. An impact study of Big Brothers/Big Sisters. Philadelphia, PA: Public/Private Ventures.

Wasiak, J. (2011) The development of development: A post-Marxist analysis of the development of hegemonic developmental psychology. Annual Review of Critical Psychology, 9, 118125.

Wodak, R. (2011). Critical linguistics and critical discourse analysis. In Jan Zienkowski, J-O. Östman, \& J. Verschueren (Eds.), Discursive pragmatics [Handbook of Pragmatics Highlights, 8] (pp. 50-70).

Wodak, R., \& Meyer, M. (Eds.). (2001). Methods of critical discourse analysis (1st ed.). London, UK: SAGE. 